\title{
Assays for Qualification and Quality Stratification of Clinical Biospecimens Used in Research: A Technical Report from the ISBER Biospecimen Science Working Group
}

\author{
Fay Betsou, Alexandre Bulla, Sang Yun Cho, Judith Clements, ${ }^{4}$ Rodrigo Chuaqui, Domenico Coppola, \\ Yvonne De Souza, Annemieke De Wilde, William Grizzle, ${ }^{9}$ Fiorella Guadagni, ${ }^{10}$ Elaine Gunter, ${ }^{11}$ \\ Stacey Heil, ${ }^{12}$ Verity Hodgkinson, ${ }^{13}$ Joseph Kessler, ${ }^{14}$ Michael Kiehntopf, ${ }^{15}$ Hee Sung Kim, ${ }^{16}$ \\ Iren Koppandi, ${ }^{17}$ Katheryn Shea, ${ }^{18}$ Rajeev Singh,, ${ }^{19}$ Marc Sobel, ${ }^{20}$ Stella Somiari, ${ }^{21}$ Demetri Spyropoulos, ${ }^{22}$ \\ Mars Stone ${ }^{23}$ Gunnel Tybring, ${ }^{24}$ Klara Valyi-Nagy, ${ }^{25}$ Gert Van den Eynden,, and Lalita Wadhwa ${ }^{27}$
}

This technical report presents quality control (QC) assays that can be performed in order to qualify clinical biospecimens that have been biobanked for use in research. Some QC assays are specific to a disease area. Some QC assays are specific to a particular downstream analytical platform. When such a qualification is not possible, QC assays are presented that can be performed to stratify clinical biospecimens according to their biomolecular quality.

Keywords: quality control, biospecimen, qualification, tissue, cells, biological fluid

\section{Introduction}

CINICAL BIOSPECIMENS USED in research are subject to two types of laboratory analyses. The first of these is the analysis of established clinical biology/pathology parameters where reference ranges are usually known and methods are validated (e.g., CLIA or ISO15189 accreditation). Results of these analyses are necessary to support any

\footnotetext{
${ }^{1}$ Integrated BioBank of Luxemburg (IBBL), Luxembourg, Luxembourg.

${ }^{2}$ Biotheque-SML, Division of Genetics and Laboratory Medicine (DMGL), University Hospital of Geneva, Geneva, Switzerland.

${ }^{3}$ National Biobank of Korea, Cheongju, South Korea.

${ }^{4}$ Australian Prostate Cancer Bioresource/Queensland University of Technology, Brisbane, Australia.

${ }^{5}$ Cancer Diagnosis Program, Division of Cancer Treatment and Diagnosis (DCTD), National Cancer Institute, Rockville, Maryland.

${ }^{6}$ Moffitt Cancer Center, Department of Anatomic Pathology, University of South Florida, Tampa, Florida.

${ }^{7}$ University of California, San Francisco, AIDS Specimen Bank, San Francisco, California.

${ }^{8}$ Universitair Ziekenhuis Antwerpen, Edegem, Belgium.

${ }^{9}$ University of Alabama at Birmingham, Birmingham, Alabama.

${ }^{10}$ San Raffaele Rome University-IRCCS San Raffaele Pisana, Rome, Italy.

${ }^{11}$ Specimen Solutions, LLC, Tucker, Georgia.

${ }_{13}^{12}$ Coriell Institute for Medical Research, Camden, New Jersey.

${ }^{13}$ Cancer Research Division, Cancer Council NSW, Woolloomooloo, Australia.

${ }^{14}$ Medpace Reference Laboratories, Cincinnati, Ohio.

${ }^{15}$ Universitätsklinikum Jena, Jena, Germany.

${ }^{16}$ Department of Pathology, Chung-Ang University College of Medicine, Dongjak-gu, South Korea.

${ }^{17}$ Cellular Technology Ltd, Shaker Heights, Ohio.

${ }^{18}$ Precision for Medicine, Inc., Frederick, Maryland.

${ }^{19}$ Houston Methodist Research Institute, Biorepository, Houston, Texas.

${ }^{20}$ American Society for Investigative Pathology, Bethesda, Maryland.

${ }^{21}$ Biobank and Biospecimen Science Research, Windber Research Institute, Windber, Pennsylvania.

${ }^{22}$ Department of Pathology and Laboratory Medicine, Children's Research Institute, Medical University of South Carolina, Charleston, South Carolina.

${ }^{23}$ Blood Systems Research Institute, San Francisco, California.

${ }_{25}^{24}$ Karolinska Institutet, Stockholm, Sweden.

${ }^{25}$ University of Illinois Biorepository, Department of Pathology, College of Medicine, University of Illinois at Chicago, Chicago, Illinois.

${ }^{26}$ Department of Pathology and Cytology, GZA Hospitals, Wilrijk, Belgium.

${ }^{27}$ Baylor College of Medicine, Houston, Texas.

(C) Fay Betsou et al., 2016; Published by Mary Ann Liebert, Inc. This Open Access article is distributed under the terms of the Creative Commons License (http://creativecommons.org/licenses/by/4.0), which permits unrestricted use, distribution, and reproduction in any medium, provided the original work is properly cited.
} 
research on novel clinically relevant biomarkers (definition of true positive and negative cases, use as a reference method). The second type is analysis of research parameters where there are usually no established reference ranges, and often methods are not validated by the laboratory as extensively as clinical biology/pathology methods. ${ }^{1}$ Results of these analyses are used to discover novel clinical endpoint correlates (biomarkers).

In vivo and in vitro pre-analytical variations have a more or less significant impact on the output of analyses, depending on the biospecimen type, the pre-analytical variable, and the analyte of interest. According to the type of analysis above, the word "significant" has a different meaning. In the first typethe analysis of clinical biology/pathology parameters"significant" means clinically consequential at the diagnostic level. In the second type-analysis of research parameters"significant" means statistically significant. Examples illustrating this concept are shown in Table 1.

In some cases, the impact may be molecule- and even epitope-specific, for example tissue ischemia time may influence specific phospho-epitopes differently. A standard biospecimen research experimental protocol has been proposed for this type of research. ${ }^{2}$

Therefore, in all research comparing different groups of samples for biomarker discovery, it is critical that all samples are of comparable quality to avoid the introduction of uncontrolled variables and increase the power of analysis of biomarkers. There are two approaches to this end: either sample collections with careful pre-analytical annotations (SPREC), ${ }^{3}$ or retrospective collections with appropriate quality control (QC) and sample qualification or quality stratification. A combination of the two approaches to control compliance of procedures with specified SPRECs is also possible.

Biobanks underpin all three layers of biomarker discovery, validation, and use in clinical practice. In the biomarker discovery phase, biospecimens collected and processed with one Standard Operating Procedure (SOP), and corresponding to one quality category, should be used in order to avoid preanalytical bias and increase the power of research. However, in the biomarker validation phase, biospecimens collected and processed with more than one known and documented SOPs and corresponding to more than one quality category should be used in order to validate the robustness of a bio- marker to relevant pre-analytical variations. Finally, in the biomarker clinical implementation phase, biospecimens collected and processed via validated SOPs should be used in order to ensure successful and accurate clinical diagnostic results. For these reasons, during recent years, biobank managers, auditors, and funding bodies have been asking what assays can be performed in order to assess the quality of biospecimens objectively. This technical review provides answers to this question. Although gaps exist, this review shows that many tools are already available and can be used for specimen qualification.

\section{Methods}

For the purposes of this technical report, the members of the International Society for Biological and Environmental Repositories (ISBER) Biospecimen Science Working Group held face-to-face meetings and teleconferences between 2013 and 2015. The chair of the Working Group performed a thorough literature review and compiled a list of relevant and effective QC attributes for different categories of biospecimens. This list was reviewed and complemented by members of the Working Group. When the information is based on published evidence, the corresponding reference is given. When no reference is given, the information corresponds to current practice or to the corresponding author's opinion.

The following definitions were used:

- Biospecimen: any biological specimen, which may be a:

- Primary sample: specimen directly collected from the donor (e.g., whole blood, urine, solid tissue);

- Simple derivative: sample prepared through a simple laboratory manipulation (e.g., after centrifugation of collection tubes or mechanical disruption of tissues) without the addition of chemical substances, and without cell disruption or cell selection as part of a multi-step process; or

- Complex derivative: derivative whose isolation requires usage of multiple steps and/or addition of chemical substances (e.g., nucleic acids, proteins, lipids, sorted cells, cultured cells, immortalized cells).

- Qualification: process of examination of a biospecimen or a collection of biospecimens, and verification, based on

Table 1. Examples Illustrating the Probable Impact of Pre-Analytical Conditions on the ANalysis of Clinical or Research Parameters

\begin{tabular}{|c|c|c|c|}
\hline Pre-analytical condition & $\begin{array}{l}\text { Biospecimen } \\
\text { type }\end{array}$ & Analyzed parameter & $\begin{array}{c}\text { Probable impact on the } \\
\text { output of analyses }\end{array}$ \\
\hline $\begin{array}{l}\text { Pre-centrifugation } \\
\text { conditions }\end{array}$ & Serum & Clinical antibodies (e.g., anti-EBV IgG) & Non-significant (clinically) \\
\hline $\begin{array}{l}\text { Pre-centrifugation } \\
\text { conditions }\end{array}$ & Serum & Research cytokines (e.g., IL-8) & Significant (statistically) \\
\hline $\begin{array}{l}\text { Pre-centrifugation } \\
\text { conditions }\end{array}$ & Citrate plasma & Research cytokines (e.g., IL-8) & Non-significant (statistically) \\
\hline $\begin{array}{l}\text { Pre-centrifugation } \\
\text { conditions }\end{array}$ & Citrate plasma & $\begin{array}{l}\text { Coagulation parameters (e.g., factor V, } \\
\text { factor VIII) }\end{array}$ & Significant (clinically) \\
\hline Formalin fixation time & Lung tissue & IHC clinical antibodies (e.g., CK7) & Non-significant (clinically) \\
\hline Formalin fixation time & Lung tissue & $\begin{array}{l}\text { Mutation analysis by next-generation } \\
\text { sequencing (e.g., allele frequency }<10 \%)\end{array}$ & $\begin{array}{l}\text { Significant (not detectable } \\
\text { mutation) }\end{array}$ \\
\hline Alcohol fixation time & Lung tissue & $\begin{array}{l}\text { Mutation analysis by next-generation } \\
\text { sequencing (e.g., allele frequency }<10 \%)\end{array}$ & $\begin{array}{l}\text { Non-significant (detectable } \\
\text { mutation) }\end{array}$ \\
\hline
\end{tabular}

CK7, cytokeratin 7; EBV, Epstein-Barr virus; IgG, immunoglobulin G; IHC, immunohistochemistry; IL8, interleukin 8. 
objective analytical evidence, of their suitability for research use, either in a specific disease area or on a specific downstream analytical platform.

- Quality stratification: process of examination of a biospecimen or a collection of biospecimens, and their classification, based on objective analytical evidence, into distinct categories, each category corresponding to a specific in vivo biological characteristic (e.g., level of inflammation, \% tumor, protein content) or to a specific ex vivo pre-analytical condition (e.g., pre-centrifugation conditions).

- Biomolecular integrity: quality status of a biospecimen, reflecting whether biomolecules of interest have not un- dergone either statistically or clinically significant changes relative to their in vivo state/levels.

- Commutability: equivalence of analytical methods, based on objective evidence.

The term "qualification" is used qualitatively. Therefore, a biospecimen is or is not qualified for use in research in a specific disease area or on a specific analytical platform.

The term "quality stratification" is used quantitatively. Therefore, one or more thresholds apply in order to stratify biospecimens in two or more quality categories. These quality categories correspond to defined in vivo or in vitro conditions.

Table 2. QC Measurands for Qualification for Use in Specific Disease Areas

\begin{tabular}{|c|c|c|c|}
\hline Biospecimen type & Measurand & $\begin{array}{l}\text { Scope of qualification } \\
\quad \text { (disease area) }\end{array}$ & Measurement method \\
\hline \multirow[t]{4}{*}{ Serum } & $\begin{array}{l}\text { Brain natriuretic peptide (BNP), } \\
\text { NT-proBNP }\end{array}$ & \multirow[t]{4}{*}{ Cardiovascular } & EIA \\
\hline & Angiopoietin-like 3 (ANFPTL3) & & ECLIA/EIA \\
\hline & $\begin{array}{l}\text { Creatinine kinase MB isoenzyme } \\
\text { (CK-MB) }\end{array}$ & & EIA \\
\hline & Endothelin 1 (ET-1) & & \\
\hline Heparin plasma, serum & $\begin{array}{l}\text { Matrix metalloproteinase-3 (MMP-3), } \\
\text { matrix metalloproteinase-9 (MMP-9) }\end{array}$ & & EIA \\
\hline All plasma, ${ }^{\mathrm{a}}$ serum & Troponin I \& T & & ECLIA/EIA \\
\hline All plasma & Vasoactive intestinal peptide (VIP) & & EIA \\
\hline All plasma & $\begin{array}{l}\text { Cholesterol ester transfer protein activity } \\
\text { (CETP) }\end{array}$ & Lipid metabolism & Fluoroimmunoassay \\
\hline Serum & Alanine aminotransferase $(\mathrm{ALT})^{7}$ & Liver & Enzymatic assay \\
\hline Serum, all plasma & Tumor necrosis factor alpha (TNF- $\alpha)$ & $\begin{array}{l}\text { Autoimmune, } \\
\text { inflammatory }\end{array}$ & Sensitive EIA \\
\hline Serum & $\begin{array}{l}\text { Insulin C peptide }{ }^{8} \\
\text { Insulin-like growth factor II precursor }\end{array}$ & $\begin{array}{l}\text { Endocrinology and } \\
\text { diabetes }\end{array}$ & $\begin{array}{l}\text { Fluoroimmunoassay, } \\
\text { EIA/RIA }\end{array}$ \\
\hline \multirow[t]{2}{*}{ All plasma } & $\begin{array}{l}\text { Glucagon-like peptide } 1 \text { (cleared by } \\
\text { DPP4) }\end{array}$ & & EIA/RIA \\
\hline & Adenocorticotrophic hormone (ACTH) & & ECLIA/RIA \\
\hline All plasma, serum & $\begin{array}{l}\text { Aldosterone } \\
\quad \text { Somatomedin } \mathrm{C}\end{array}$ & & EIA \\
\hline \multirow[t]{5}{*}{ Citrate plasma } & $\begin{array}{l}\text { Anti-factor Xa } \\
\text { Fibrinogen }\end{array}$ & \multirow[t]{5}{*}{ Coagulation } & Clot detection \\
\hline & Prothrombin fragments $1 \& 2$ & & EIA \\
\hline & $\begin{array}{l}\text { Plasminogen activator inhibitor type } 1 \\
\text { activity or antigen }\end{array}$ & & \\
\hline & Thrombin generation assay & & Fluoroimmunoassay \\
\hline & $\begin{array}{l}\text { Tissue-type plasminogen activator } \\
\text { antigen (TPA antigen) }\end{array}$ & & EIA \\
\hline Urine & Beta 2 microglobulin & Nephrology & Nephelometry, EIA/RIA \\
\hline All plasma, serum & Complement C3 & \multirow{3}{*}{$\begin{array}{l}\text { Inflammation, } \\
\text { immunology }\end{array}$} & Nepholometry, EIA \\
\hline All plasma, serum & $\begin{array}{l}\text { Intercellular adhesion molecule } 1 \\
\text { (ICAM-1) }\end{array}$ & & EIA \\
\hline $\begin{array}{l}\text { Citrate/heparin plasma, } \\
\text { serum }\end{array}$ & $\mathrm{TNF}-\alpha$ & & EIA \\
\hline Serum & M65 EpiDeath & \multirow[t]{2}{*}{ Oncology } & EIA \\
\hline Heparin plasma, serum & Vascular adhesion molecule I (VCAM-1) & & EIA \\
\hline \multirow[t]{2}{*}{ Serum } & Mid-osteocalcin, osteocalcin, calcitonin & \multirow[t]{3}{*}{ Musculoskeletal } & ECLIA, EIA \\
\hline & Parathyroid hormone, intact (PTH) & & ECLIA, EIA \\
\hline All plasma, serum & Telopeptide $\mathrm{C}$ terminal, type 1 collagen & & ECLIA, EIA \\
\hline Serum & Vitamin B12 & Nutritional & ECLIA \\
\hline CSF, serum, all plasma & Amyloid Ab42 & \multirow[t]{2}{*}{ Neurodegenerative } & EIA \\
\hline Serum, CSF & Neuron-specific enolase ${ }^{10}$ & & Kryptor immunoassay, EIA \\
\hline
\end{tabular}

${ }^{a}$ All plasma refers to all EDTA, citrate, and heparinized plasma.

CSF, cerebrospinal fluid; DPP4, dipeptidylpeptidase 4; ECLIA, electrochemiluminescent immunoassay; EIA, enzyme immunoassay; QC, quality control; RIA, radioimmunoassay. 


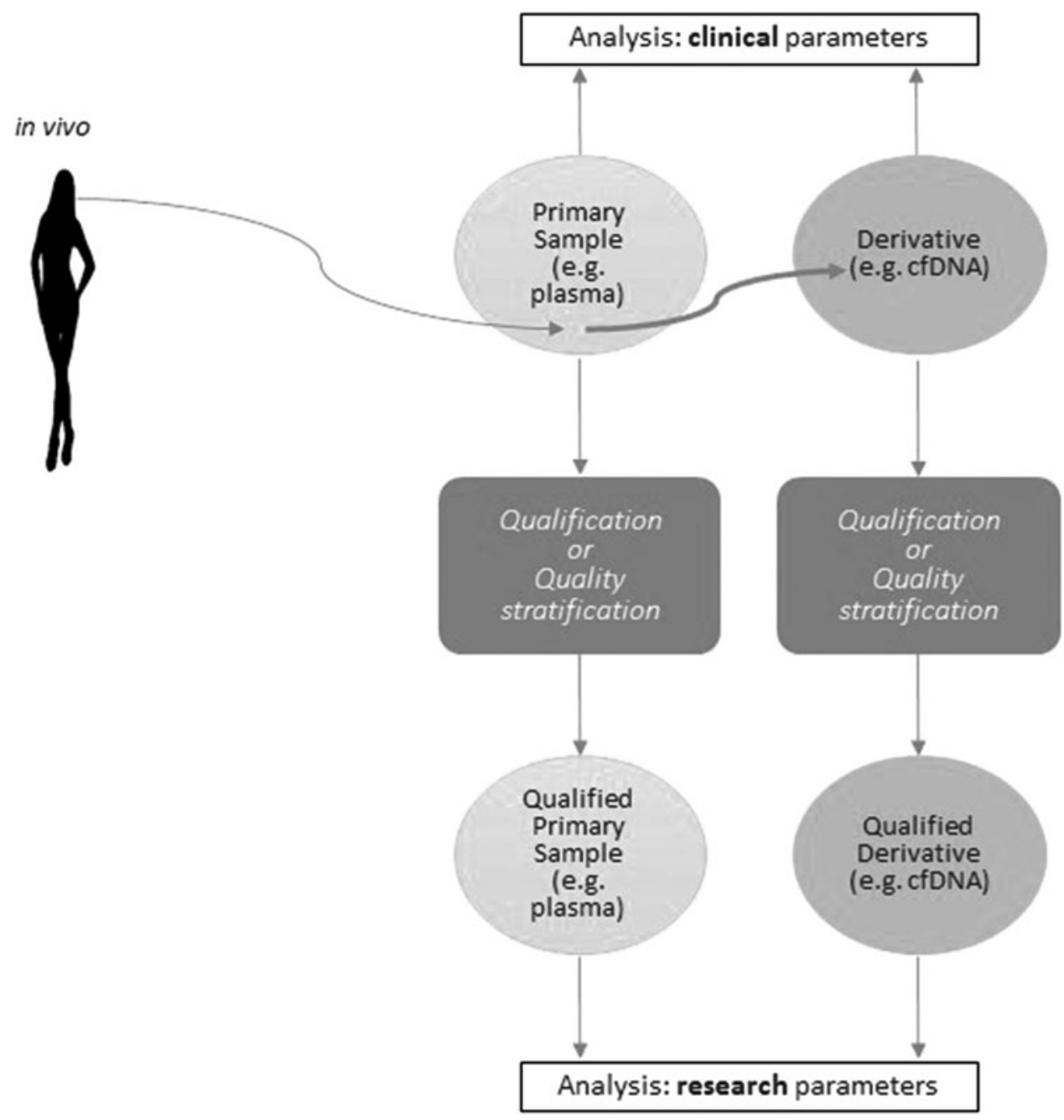

FIG. 1. Flow diagram illustrating sample preparation and qualification for use in research.

When qualification is not possible because of lack of relevant assays, then quality stratification can be made. In some cases, qualification can be achieved for biomarker research in a specific disease area (Table 2) or on a specific downstream analytical platform. For primary samples, qualification depends on their biomolecular integrity. For simple or complex derivatives, qualification depends both on the biomolecular integrity of the primary sample from which the derivative has been extracted and on the efficiency/performance of the extraction, culture,

Table 3. QC Measurands for Qualification of Fluid Biospecimens and Their Derivatives

\begin{tabular}{|c|c|c|c|c|}
\hline $\begin{array}{l}\text { Biospecimen } \\
\text { type }\end{array}$ & Qualification parameter & Measurand & Scope of qualification & $\begin{array}{l}\text { Measurement } \\
\text { method }\end{array}$ \\
\hline Cf DNA & $\begin{array}{l}\text { Contamination by blood } \\
\text { cell DNA }\end{array}$ & DNA fragment size $100-300 \mathrm{bp}^{11}$ & Cf DNA genotyping & $\begin{array}{l}\text { Microfluidic } \\
\text { electrophoresis }\end{array}$ \\
\hline \multirow[t]{2}{*}{ Cf miRNA } & Extraction efficiency & $\begin{array}{l}\text { Spike in miRNA control (www } \\
\text {.qiagen.com/lu/resources/ } \\
\text { resourcedetail?id=710c0168- } \\
\text { e408-408b-95af-91df5b5b1dd6\& } \\
\text { lang=en) }\end{array}$ & Cf miRNA analysis & qRT PCR \\
\hline & & $\begin{array}{l}\text { miRNA } 16 \text { or other ubiquitous } \\
\text { miRNA target }\end{array}$ & Cf miRNA analysis & qRT PCR \\
\hline \multirow[t]{2}{*}{ Stool DNA } & Inhibitors & SPUD $^{12}$ & PCR applications & qPCR \\
\hline & Extraction efficiency & Bacterial DNA content & Bacterial DNA analysis & qPCR \\
\hline $\begin{array}{l}\text { Whole-blood } \\
\text { cell DNA }\end{array}$ & Inhibitors & $\begin{array}{l}\text { Human DNA content } \\
\text { SPUD }^{12}\end{array}$ & $\begin{array}{l}\text { Human DNA analysis } \\
\text { PCR applications }\end{array}$ & $\begin{array}{l}\text { qPCR } \\
\text { qPCR }\end{array}$ \\
\hline
\end{tabular}

Cf, cell free; qRT PCR, quantitative reverse transcription polymerase chain reaction. 


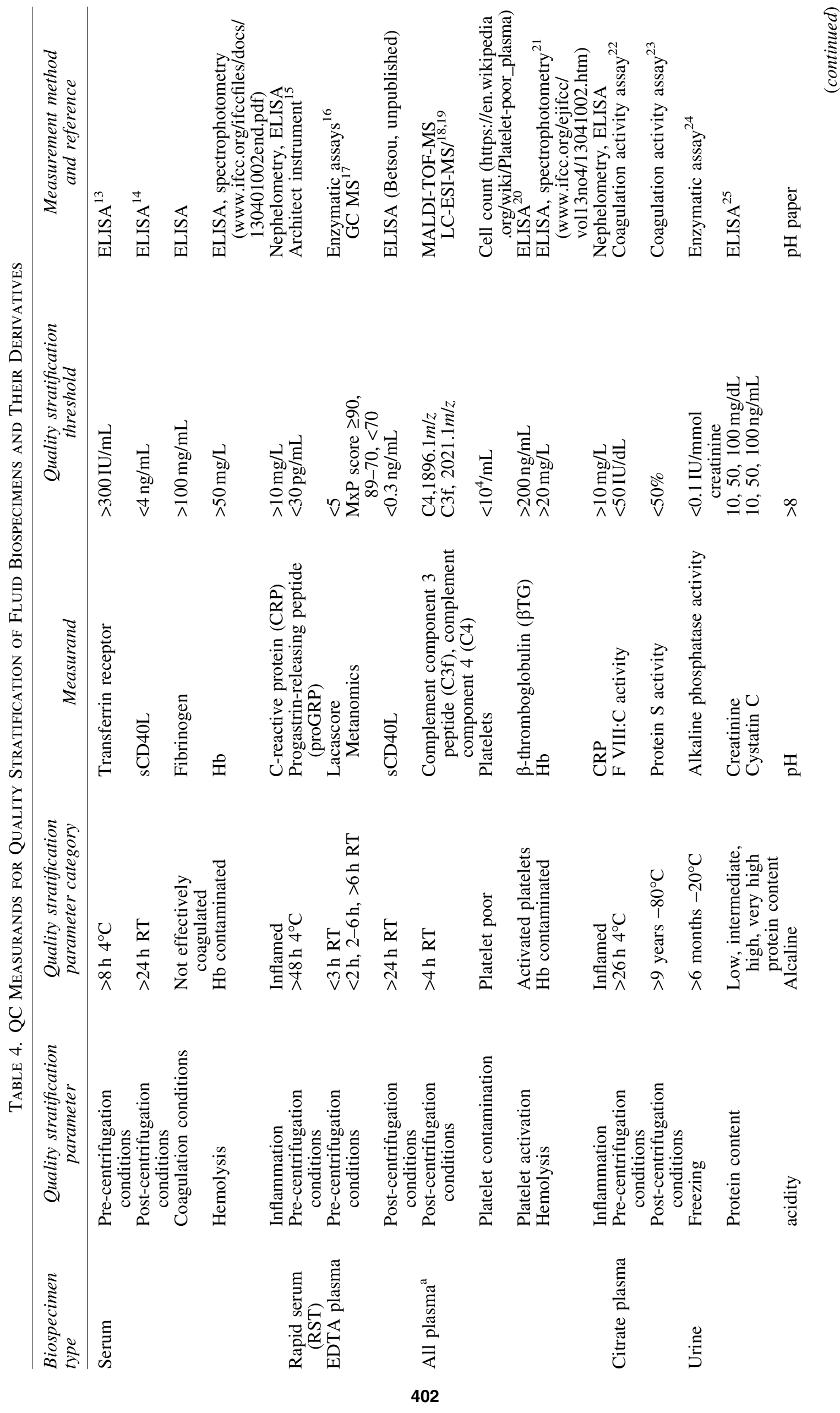




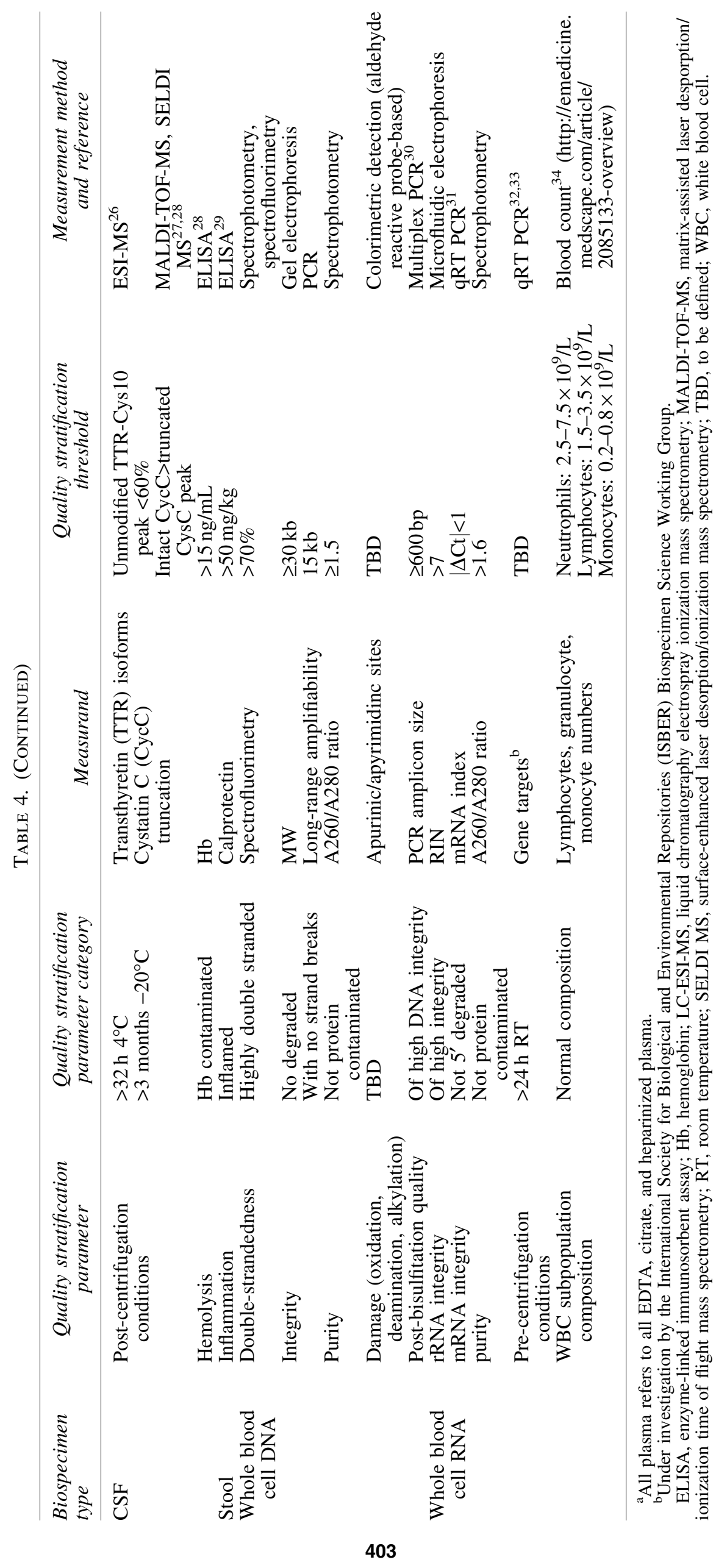


Table 5. QC Measurands for Qualification of Tissue Biospecimens and Their Derivatives

\begin{tabular}{|c|c|c|c|c|}
\hline Biospecimen type & $\begin{array}{c}\text { Qualification } \\
\text { parameter }\end{array}$ & Measurand & $\begin{array}{c}\text { Scope of } \\
\text { qualification }\end{array}$ & $\begin{array}{l}\text { Measurement } \\
\text { method }\end{array}$ \\
\hline Frozen tissue & Freeze-thaw & Cell lysis & $\begin{array}{l}\text { IHC, RNA-based } \\
\text { analyses }\end{array}$ & H\&E staining \\
\hline $\begin{array}{l}\text { Viable frozen } \\
\text { tissue }\end{array}$ & $\begin{array}{l}\text { Sterility } \\
\text { Cryopreservation } \\
\text { conditions }\end{array}$ & $\begin{array}{l}\text { Absence of } \\
\text { contaminants } \\
\text { Post-thaw } \\
\text { viability }\end{array}$ & Tissue culture & $\begin{array}{l}\text { Growth on agar; } \\
\text { mycoplasma testing } \\
\text { Growth in flasks }\end{array}$ \\
\hline
\end{tabular}

$\mathrm{H} \& \mathrm{E}$, hematoxylin and eosin.

cryopreservation, or other laboratory manipulation (e.g., cfDNA from plasma; Fig. 1).

\section{Results}

The results are presented in the form of Tables for fluid (Tables 3 and 4), tissue (Tables 5 and 6), and cytological biospecimens and their derivatives.

Table 2 includes information on QC measurands for qualification for use of samples in specific disease areas. ${ }^{4,5}$ The measurands in this table are molecules that are recognized biomarkers in the respective disease areas and are also known to be labile. Detection of the measurand above the method's level of detection is necessary (though not always sufficient) for qualification of a sample. As an example for reading Table 2, if $\mathrm{A} \beta 42$ is undetectable in CSF samples, then these samples cannot be qualified for research in the area of neurodegenerative diseases.

Tables 3, 5, and 7 include information that can be used for the qualification of fluid, tissue, or cytological specimens, respectively, in the scope of different types of downstream analyses. In these tables, "qualification parameter" is the quality aspect of the biospecimen that is being evaluated; "measurand" is the molecule, or the morphological or functional characteristic that is being measured and whose positive or negative result is necessary for the qualification; "scope of qualification" is the type of downstream analysis for which the biospecimen is being qualified as fit-forpurpose; and "measurement method" is the type of method that is used to measure the measurand.

Tables 4, 6, and 8 include information that can be used for the quality stratification of a fluid, tissue, or cytological biospecimen, respectively. In these tables, "qualification parameter" is the quality aspect of the biospecimen for which the biospecimen is being stratified; "measurand" is the molecule, or the morphological or functional characteristic that is being measured and whose level is used to stratify the biospecimens in categories; "quality stratification thresholds" are the levels of the measurand, which are critical for the quality stratification; and "measurement method" is the type of method that is used to measure the measurand. The quality stratification thresholds listed in Tables 4,6 , and 8 classify the biospecimens into the categories of the qualification parameter given. The "time xxx/ temperature yyy" categories correspond to available experimental data, but they should be understood as "time xxx/temperature yyy or equivalent conditions." The quality stratification thresholds listed in Tables 4, 6, and 8 are those corresponding to the measurement methods described in the references. Application of a threshold with a measurement method that is different from the method that has been used for the establishment of the threshold requires previous demonstration of the commutability of the methods.

\section{Tissue type specificities}

Assays for tissue qualification or quality stratification may be tissue type-specific. Some examples are given below. Fixation conditions have a significant impact on P-Akt and P-Erk $1 / 2$ in breast cancer tissue. ${ }^{35}$ Ischemia has a significant impact on estrogen and progesterone receptors in breast tissue. $^{36,37}$ A Tissue Quality Index has been proposed for formalin-fixed, paraffin-embedded breast tissue in order to assess its cold ischemia time by immunohistochemistry. ${ }^{38}$ Stathmin ${ }^{2-20}$ has been proposed as indicator of degradation in brain tissue by matrix-assisted laser desorption/ionization time of flight mass spectrometry. ${ }^{39}$ AKT-P has been proposed as indicator of postmortem conditions in brain tissue by western blot. ${ }^{40}$ Superoxide dismutase in the liver and peptidyl-prolyl-cis-trans isomerase and insulin C-peptides in the pancreas have been associated with postmortem delay and assessed by two-dimensional difference in gel electrophoresis. $^{41}$

\section{Discussion}

This article proposes a biospecimen QC strategy, based on current state of knowledge, in the form of summary tables (Fig. 2).

The qualification and quality stratification assays presented in this technical report do not aim for an absolute assessment of the quality of samples, since a sample can be of high enough quality (fit-for-purpose) for one type of analysis (e.g., antibody analysis), but not for other types of analyses (e.g., metabolite analysis). Therefore, scientists should devote time and effort to understand and define what sample quality is needed to obtain consistent results with a given downstream analytical platform. As can be seen from Tables 3, 5, and 7, there are several gaps in the area of biospecimen qualification for use on specific analytical platforms. These include, for example, urine, saliva, or frozen tissue qualification for use in proteomic analyses, serum, plasma, or other body fluid qualification for use in miRNome analyses, or DNA qualification for use in methylation analyses. In the absence of such knowledge, this technical report offers a strategy for sample quality stratification so that bias due to samples of inconsistent quality levels can be minimized. 


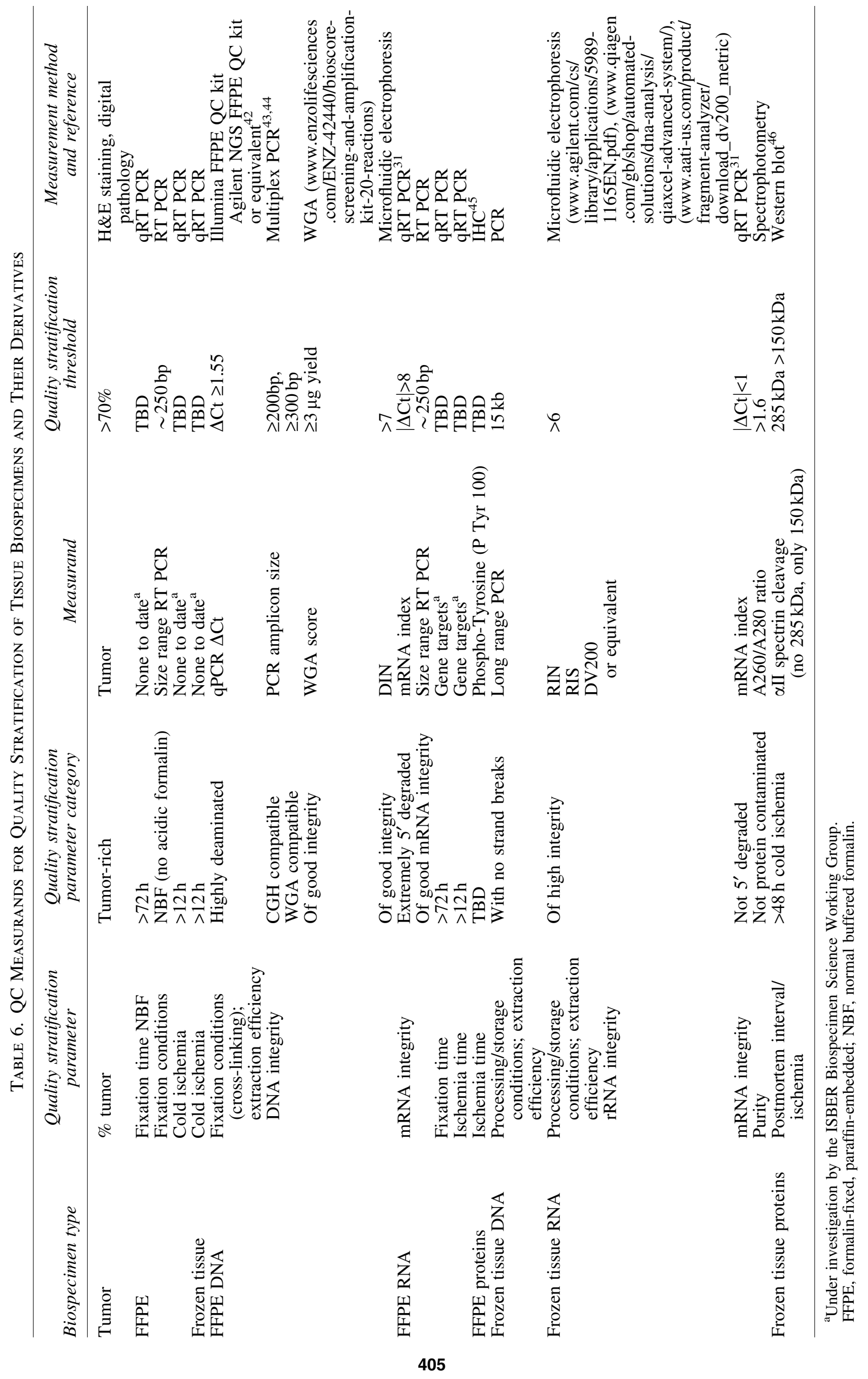




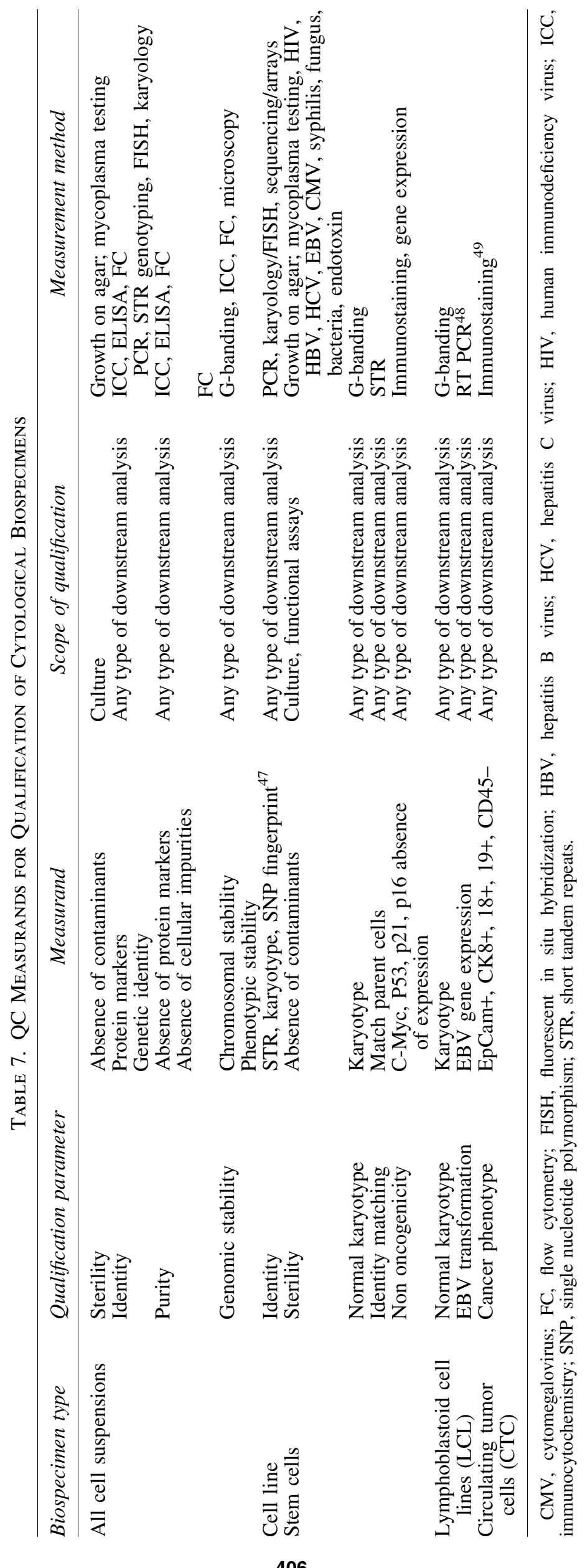




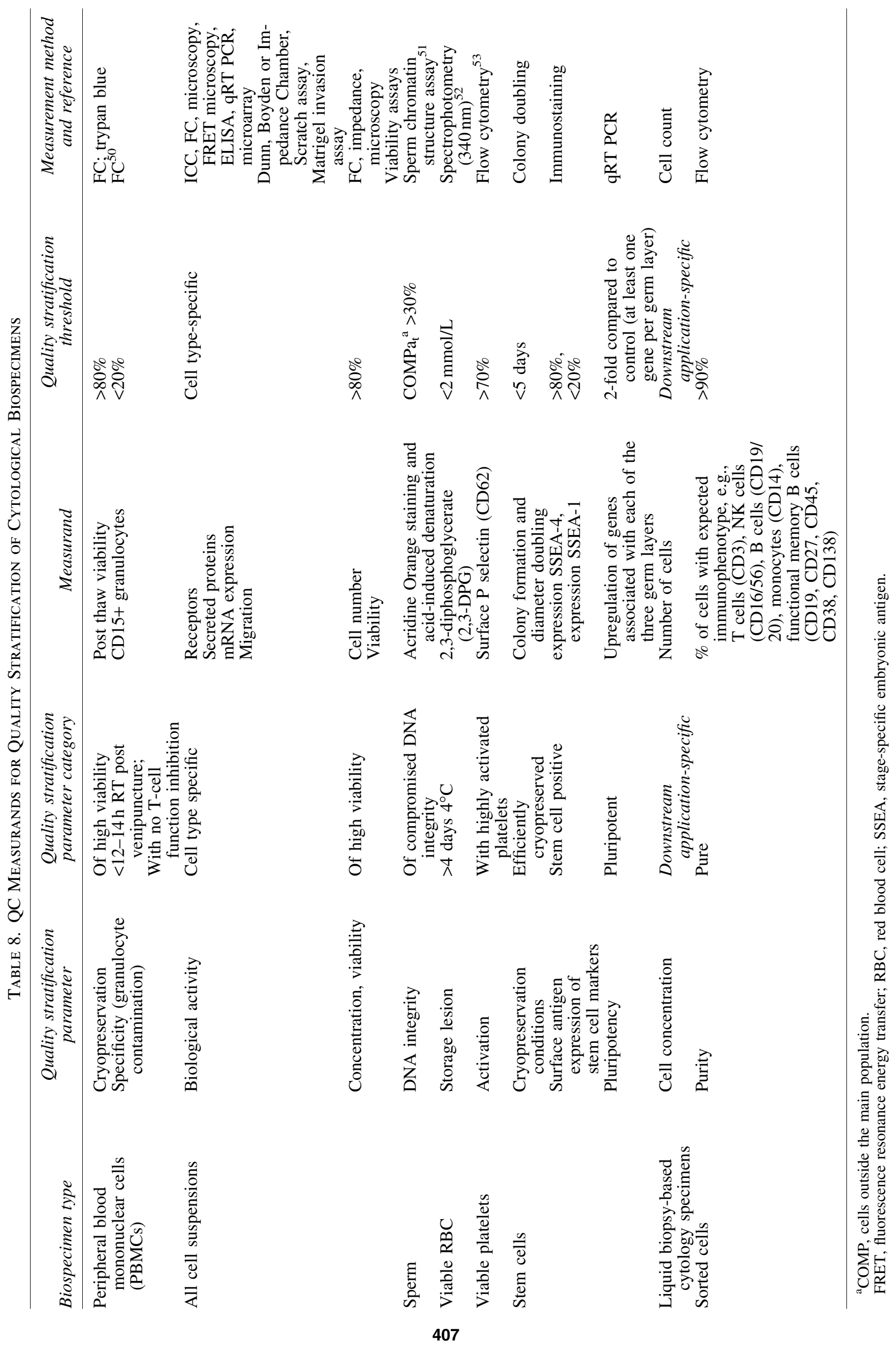




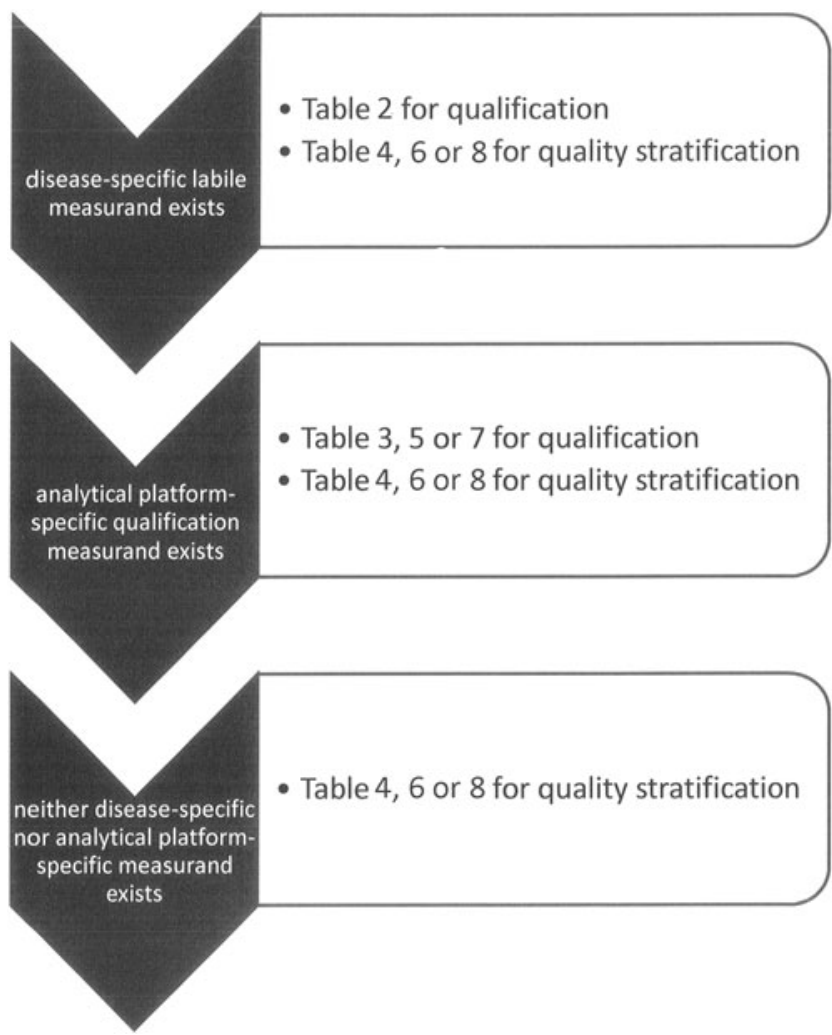

FIG. 2. Decision tree for any given specimen type.

The information provided in this report is important because its application will enable and support bioprocessing method validation by providing relevant readouts (measurands); assessment of the quality of biospecimens of unknown history; biomarker discovery by ensuring use of qualified biospecimens or biospecimens belonging to a specific quality category; validation of biomarker robustness by using quality-stratified biospecimens belonging to different, defined quality categories; implementation of novel biomarkers in clinical practice; and characterization and production of clinical reference materials.

For the above purposes, QC measurands of clinical biospecimens can be assessed either by the biobanks themselves, or by subcontractors/collaborators who are accredited or successfully participate in relevant Proficiency Testing schemes. The results of the QC can be used by biobanks for qualification of legacy collections (the definition of cutoff values for acceptance of legacy collections or specific samples can be made and disclosed by the biobank), by end users for stratification of samples of different origins, or by funding agencies for assessment of the fitness for purpose of collections to be used in the context of grant allocation.

\section{Author Disclosure Statement}

F.B. is listed as co-inventor in patent no. 0704237 and in the filed patent 15195301.5-1408 (on sCD40L and LacaScore, respectively).

\section{References}

1. Cummings J, Raynaud F, Jones L, et al. Fit-for-purpose biomarker method validation for application in clinical trials of anticancer drugs. Br J Cancer 2010;103:1313-1317.
2. Betsou F, Barnes R, Burke T, et al. Human biospecimen research: experimental protocol and quality control tools. Cancer Epidemiol Biomarkers Prev 2009;18:1017-1025.

3. Lehmann S, Guadagni F, Moore H, et al. Standard preanalytical coding for biospecimens: review and implementation of the Sample PREanalytical Code (SPREC). Biopreserv Biobank 2012;10:366-374.

4. Siest G, Henny J, Schiele F. Références en Biologie Clinique. Paris: Elsévier;1990.

5. Ghnassia J-C. Échantillons Biologiques Phase Préanalytique et Prélèvements en Biologie Médicale. Paris: Elsévier;1998.

6. Belenky A, Smith A, Zhang B, et al. The effect of class-specific protease inhibitors on the stabilization of B-type natriuretic peptide in human plasma. Clin Chim Acta 2004;340:163-172.

7. Williams KM, Williams AE, Kline LM, et al. Stability of serum alanine aminotransferase activity. Transfusion 1987;27: 431-433.

8. Gislefoss RE, Grimsrud TK, Morkrid L. Stability of selected serum proteins after long-term storage in the Janus Serum Bank. Clin Chem Lab Med 2009;47:596-603.

9. Kim W, Egan JM. The role of incretins in glucose homeostasis and diabetes treatment. Pharmacol Rev 2008; 60:470-512.

10. Ramont L, Thoannes H, Volondat A, et al. Effects of hemolysis and storage condition on neuron-specific enolase (NSE) in cerebrospinal fluid and serum: implications in clinical practice. Clin Chem Lab Med 2005;43:12151217.

11. Breitbach $S$, Tug $S$, Helmig $S$, et al. Direct quantification of cell-free, circulating DNA from unpurified plasma. PLoS One 2014;9.

12. Nolan T, Hands RE, Ogunkolade W, et al. SPUD: a quantitative PCR assay for the detection of inhibitors in nucleic acid preparations. Anal Biochem 2006;351:308-310.

13. De Jongh R, Vranken J, Vundelinckx G, et al. The effects of anticoagulation and processing on assays of IL-6, sIL6R, sIL-2R and soluble transferrin receptor. Cytokine 1997; 9:696-701.

14. Lengelle J, Panopoulos E, Betsou F. Soluble CD40 ligand as a biomarker for storage-related preanalytic variations of human serum. Cytokine 2008;44:275-282.

15. Korse CM, Holdenrieder S, Zhi XY, et al. Multicenter evaluation of a new progastrin-releasing peptide (ProGRP) immunoassay across Europe and China. Clin Chim Acta 2015;438:388-395.

16. Trezzi J-P, Bulla A, Bellora C, et al. LacaScore: a novel plasma sample quality control tool based on ascorbic acid and lactic acid levels. Metabolomics 2016; in press.

17. Kamlage B, Maldonado SG, Bethan B, et al. Quality markers addressing preanalytical variations of blood and plasma processing identified by broad and targeted metabolite profiling. Clin Chem 2014;60:399-412.

18. Yi J, Kim C, Gelfand CA. Inhibition of intrinsic proteolytic activities moderates preanalytical variability and instability of human plasma. J Proteome Res 2007;6: 1768-1781.

19. Marshall J, Kupchak P, Zhu W, et al. Processing of serum proteins underlies the mass spectral fingerprinting of myocardial infarction. J Proteome Res 2003;2:361-372.

20. Chong BH, Murray B, Berndt MC, et al. Plasma P-selectin is increased in thrombotic consumptive platelet disorders. Blood 1994;83:1535-1541.

21. Thomas L. Haemolysis as influence and interference factor. Available at www.ifcc.org/ifccfiles/docs/130401002end.pdf (accessed March 30, 2016). 
22. Carlebjork G, Blomback M, Akerblom O. Improvement of plasma quality as raw material for factor VIII:C concentrates. Storage of whole blood and plasma and interindividual plasma levels of fibrinopeptide A. Vox Sang 1983; 45:233-242.

23. Betsou F, Roussel B, Guillaume N, et al. Long-term stability of coagulation variables: protein $\mathrm{S}$ as a biomarker for preanalytical storage-related variations in human plasma. Thromb Haemost 2009;101:1172-1175.

24. Berg KJ, Kristoffersen DT, Djoseland O, et al. Reference range of some enzymes and proteins in untimed overnight urine and their stability after freezing. Clin Chim Acta 1998;272:225-230.

25. Uchida K, Gotoh A. Measurement of cystatin-C and creatinine in urine. Clin Chim Acta 2002;323:121-128.

26. Poulsen K, Bahl JM, Tanassi JT, et al. Characterization and stability of transthyretin isoforms in cerebrospinal fluid examined by immunoprecipitation and high-resolution mass spectrometry of intact protein. Methods 2012;56:284292.

27. Hansson SF, Simonsen AH, Zetterberg H, et al. Cystatin C in cerebrospinal fluid and multiple sclerosis. Ann Neurol 2007;62:193-196; discussion 205.

28. Greco V, Pieragostino D, Piras C, et al. Direct analytical sample quality assessment for biomarker investigation: qualifying cerebrospinal fluid samples. Proteomics 2014;14: 1954-1962.

29. Tibble JA, Bjarnason I. Fecal calprotectin as an index of intestinal inflammation. Drugs Today (Barc) 2001;37:8596.

30. Ehrich M, Zoll S, Sur S, et al. A new method for accurate assessment of DNA quality after bisulfite treatment. Nucleic Acids Res 2007;35:e29.

31. Vermeulen J, De Preter K, Lefever S, et al. Measurable impact of RNA quality on gene expression results from quantitative PCR. Nucleic Acids Res 2011;39:e63.

32. Debey S, Schoenbeck U, Hellmich M, et al. Comparison of different isolation techniques prior gene expression profiling of blood derived cells: impact on physiological responses, on overall expression and the role of different cell types. Pharmacogenomics J 2004;4:193-207.

33. Benita Y, Kikuchi H, Smith AD, et al. An integrative genomics approach identifies Hypoxia Inducible Factor-1 (HIF-1)-target genes that form the core response to hypoxia. Nucleic Acids Res 2009;37:4587-4602.

34. Curry CV. Differential Blood Count Medscape. Available at: http://emedicine.medscape.com/article/2085133-overview (accessed March 30, 2016).

35. Pinhel IF, Macneill FA, Hills MJ, et al. Extreme loss of immunoreactive $\mathrm{p}$-Akt and $\mathrm{p}$-Erk1/2 during routine fixation of primary breast cancer. Breast Cancer Res 2010;12:R76.

36. Masood S, von Wasielewski R, Mengel M, et al. Influence of fixation, antibody clones, and signal amplification on steroid receptor analysis. Breast J 1998;4:33-40.

37. Yildiz-Aktas IZ, Dabbs DJ, Bhargava R. The effect of cold ischemic time on the immunohistochemical evaluation of estrogen receptor, progesterone receptor, and HER2 expression in invasive breast carcinoma. Mod Pathol 2012;25: 1098-1105.

38. Neumeister VM, Parisi F, England AM, et al. A tissue quality index: an intrinsic control for measurement of effects of preanalytical variables on FFPE tissue. Lab Invest 2014;94:467-474.
39. Skold K, Svensson M, Norrman M, et al. The significance of biochemical and molecular sample integrity in brain proteomics and peptidomics: stathmin 2-20 and peptides as sample quality indicators. Proteomics 2007;7:4445-4456.

40. Ferrer I, Santpere G, Arzberger T, et al. Brain protein preservation largely depends on the postmortem storage temperature: implications for study of proteins in human neurologic diseases and management of brain banks: a BrainNet Europe Study. J Neuropathol Exp Neurol 2007;66:35-46.

41. Scholz B, Skold K, Kultima K, et al. Impact of temperature dependent sampling procedures in proteomics and peptidomics - a characterization of the liver and pancreas post mortem degradome. Mol Cell Proteomics 2011;10.

42. Serizawa M, Yokota T, Hosokawa A, et al. The efficacy of uracil DNA glycosylase pretreatment in amplicon-based massively parallel sequencing with DNA extracted from archived formalin-fixed paraffin-embedded esophageal cancer tissues. Cancer Genet 2015;208:415-427.

43. van Beers EH, Joosse SA, Ligtenberg MJ, et al. A multiplex PCR predictor for aCGH success of FFPE samples. $\mathrm{Br}$ J Cancer 2006;94:333-337.

44. Wang F, Wang L, Briggs C, et al. DNA degradation test predicts success in whole-genome amplification from diverse clinical samples. J Mol Diagn 2007;9:441-451.

45. Gajadhar AS, Johnson H, Slebos RJ, et al. Phosphotyrosine signaling analysis in human tumors is confounded by systemic ischemia-driven artifacts and intra-specimen heterogeneity. Cancer Res 2015;75:1495-1503.

46. Li J, Kil C, Considine $\mathrm{K}$, et al. Intrinsic indicators for specimen degradation. Lab Invest 2013;93:242-253.

47. Dirks WG, Drexler HG. Authentication of scientific human cell lines: easy-to-use DNA fingerprinting. Methods Mol Biol 2005;290:35-50.

48. Jeon JP, Nam HY, Shim SM, et al. Sustained viral activity of Epstein-Barr virus contributes to cellular immortalization of lymphoblastoid cell lines. Mol Cells 2009;27:143-148.

49. Lowes LE, Hedley BD, Keeney M, et al. User-defined protein marker assay development for characterization of circulating tumor cells using the CellSearch ${ }^{\circledR}$ system. Cytometry A 2012;81:983-995.

50. McKenna KC, Beatty KM, Vicetti Miguel R, et al. Delayed processing of blood increases the frequency of activated CD11b+ CD15+ granulocytes which inhibit T cell function. J Immunol Methods 2009;341:68-75.

51. Evenson D, Jost L. Sperm chromatin structure assay is useful for fertility assessment. Methods Cell Sci 2000;22:169-189.

52. Bennett-Guerrero E, Veldman TH, Doctor A, et al. Evolution of adverse changes in stored RBCs. Proc Natl Acad Sci U S A 2007; 104:17063-17068.

53. Holme S, Sweeney JD, Sawyer S, et al. The expression of p-selectin during collection, processing, and storage of platelet concentrates: relationship to loss of in vivo viability. Transfusion 1997;37:12-17.

Address correspondence to: Fay Betsou, PhD Integrated BioBank of Luxemburg 6 rue Nicolas Ernest Barblé L-1210 Luxembourg Luxembourg

E-mail: fay.betsou@ibbl.lu 